\title{
原著
}

\section{精神障害者の家族のケア提供上の対処： 家族の応答性と自己配虑}

$$
\begin{aligned}
& \text { 岩 㠃 弥 生 }{ }^{* 1} \text {, 石川 かおり*1, 清 水邦子*1 } \\
& \text { 宮 㟝 澄子*2 }
\end{aligned}
$$

\section{Coping in Family Caregiving for Relatives with Mental Illness: Family Responsiveness and Self-Nurturing}

\author{
Yayoi Iwasaki $^{* 1}$, Kaori Ishikawa ${ }^{* 1}$, Kuniko Shimizu ${ }^{* 1}$ \\ Sumiko Miyazaki*2 \\ ${ }^{* 1}$ Chiba University School of Nursing \\ ${ }^{* 2}$ Previously at Chiba University School of Nursing
}

キーワード : 精神障害, 家族，ケア提供, 対処

Key Words : mental illness, family, caregiving, coping

\section{Abstract}

A qualitative study was conducted to identify an explanatory model which describes coping in family caregiving for relatives with mental illness. Thirty four family members provided written consent to be interviewed. Analysis of data revealed four coping styles in family caregiving.

a) Co-prosperous style: family caregivers empathically attend to needs of the ill relative in addition to their own.

b) Fused style: family caregivers are deeply involved with the ill relative, sometimes at the cost of their own needs.

c) Self-protective style: family caregivers are primarily concerned about their own needs.

d) Demoralized style: needs of both the ill relative and the family caregiver are disregard.

The four styles are explained by "family responsiveness" to the welfare of the ill relative and "family self-nurturing" of their own well-being. Responsiveness and self-nurturing are both high in the co-prosperous style and both low in the demoralized style. Responsiveness is high and self-nurturing is low in the fused style, while responsiveness is low and self-nurturing is high in the self-protective style. Family coping style is not static, and family caregivers move between coping styles to resolve conflicts between family responsiveness and self-nurturing. These findings suggest the need to assist families in finding a balance between responsiveness and self-nurturing. The findings also indicate the importance of improving the well-being of both the ill relative and the family.

$* 1$ 千葉大学看護学部, $* 2$ 元千葉大学看護学部 


\section{要旨}

精神障害者をケアする家族34名を対象に，ケア提供上の対処の特徵を明らかにすること を目的として，インタビュー調査を実施した。

デー夕分析には，質的分析方法である分析的コーディングの技法を用いた。家族の基本的 な対処様式として, (1)障害者と家族双方のニーズが満たされている共栄型, (2)障害者のニー ズを優先する一体型, (3)家族のニーズを優先する自己保存型, (4)障害者と家族のニーズど ちらも満たされない無力型が析出された.

家族の対処様式は，家族が障害者のニーズに共感的に応じる『家族の応答性』と，家族 が家族自身のニーズに配慮する『家族の自己配慮』という二つの軸の組み合わせで説明され ると考えられ, 家族と障害者双方の生活の質を保障する働きかけの必要性が示唆された.

また，家族には『応答性』と『自己配慮』間の葛藤が潜在し，家族は，ライフサイクル 等の影響による葛藤の顕在化に伴い，対処様式間を移動すると考えられた.

\section{I はじめに}

平成 8年 (1996年)の精神保健福祉法への改正 をもって, 精神障害者の地域ケアがより一層重 視されるようになり，精神障害者のケアは施設 内から地域へ，長期入院から短期入院集中治療 へと変遷している．また，「障害者プラン〜ノー マライゼイション7か年戦略〜」のもとに, 精神 障害者の社会参加を中心とした地域保健福祉が 推奨され，2002年までに達成すべき社会復帰施 設や福祉施策の具体的な目標が提示されている. たたしこれらの数值目標は絶対的に不足してお り (浅井, 1998), 地域在住の精神障害者の多く は家族のもとで生活している(黒田他, 1997)。そ して家族が精神障害者のケアの中心的な役割を 担っている。しかし，家族は精神保健福祉従事 者から適切なサポートを受けていることは少な く, 自分たちの知識や力量に不足を感じながら 単独でケアを続けているのが現状である(岩㟝, 1998).

地域ケアの潮流の中で，家族が今後もケア提 供上重要な役割を果たしていくと考えられるが, その一方で，地域資源が未整備である現状では， 家族の困難は増大することが予測される。精神 障害者の家族に対する適切な支援システムの開 発が望まれるが，そのためには，精神障害者の 家族がケア提供上どのような困難に直面し，ケ ア提供上どのように対処しているかを明らかに
することが必要になる。

精神障害者の地域ケアが1950年代半ばから推 進されてきた英米においては，精神障害者の家 族の困難に着目した研究が数多く存在し, 家族 が日常生活のさまざまな局面で負担を経験して いることが1960年代から報告されている．家族 の負担として，ケア提供，障害者の病状や問題 行動, 精神障害に対する偏見, 保健医療従事者 の家族に対する態度等が明らかにされている (Francell et al., 1988 ; Hatfield et al., 1994 ; Iwasaki, 1995 ; Noh \& Turner, 1987). 我が国にお いても，家族が抱える困難として，将来に見通 しがたたない不安, 心身の疲労, 経済的負担, 結婚問題の気苦労, 家族関係の不安定化等が明 らかにされている(石原, 1981 ; 岡上他, 1988 ： 丹下他, 1998).

このように家族の困難に関しては研究が蓄積 されているが，家族がケア提供に際してどのよ うに対処しているかについて着目した研究は限 られている。精神保健福祉の専門家は, 障害者 とその家族がそれぞれの体験から編み出してき た対処の力を生かしていけるように関わる必要 があるとされている(Spaniolら，1987）にもかか わらず，家族の対処の全貌は明らかになってい ない。そこで, 本研究は, 精神障害者をケアす る家族成員のケア提供上の対処の特徵を明らか にして，家族への援助の方向を見出すことを目 的とした。 
研究を進めるにあたり, 家族成員, ケア提供 及びケア提供上の対処については，次のように 用語を定義した。家族成員は，精神障害者と血 縁ないし婚姻や養子縁組による関係で結ばれて いる者とした。 ケア提供は, 精神障害をもつ家 族成員の日常生活及び社会生活上のニーズを満 たすために行われる世話, 介助, 気配り, 支持, 保護，監督と定義し，ケア提供上の対処は，家 族の視点から語られたケア提供における認知 上・行動上の努力と定義した.

\section{II 研究方法}

\section{1 対象}

対象は, 地域在住の18歳以上の精神障害者を 1年以上ケアしている成人した家族成員 34 名で, 平均年齢 61 歳, 平均ケア歴 11.6 年であった (表 1)。親の占める割合, 並びに障害者との同居率 は8割前後と高かった，対象者がケアしている障 害者の平均年齢は 38.9 歳で, 大多数が分裂病の 診断を受けていた.

\section{2 倫理的配慮}

研究に先立ち, 精神保健福祉機関や家族会の 関係者に研究計画書を提出し, 調査の許可を得 て調査参加者を募った。志願者には調査参加中 の権利等を書面を用いて説明し，同意を得た。 精神障害者の同意は, 調查者自身または調查参 加者が口頭で得た。調査中は, プライバシーの 権利, 参加中断の権利及び「答えたくない質問 には答えない」権利等を保障し, 調査参加者が 敏感になる話題の取り扱いは慎重にして, 信頼 関係が十分にできてから質問するなどの配慮を した。また，録音・記録したものは厳重に保管 した.

\section{3 データ収集}

データ収集は調査参加者に対するインタビュ 一を主としたが，家族会や家族勉強会での参与 観察も併用した. インタビュー内容は, (1)ケア 提供の内容と方法, (2)ケア提供上の困難と対処 方法, (3)ケア提供に伴う家族の生活上の変化を 中心とした。インタビューは, 調査参加者が自

\section{表1 対象の概要}

\begin{tabular}{|c|c|}
\hline \multicolumn{2}{|l|}{ ケア提供者（34名：男11，女23） } \\
\hline $\begin{array}{l}\text { 平均年齢 } \\
\text { 平均ケア期間 }\end{array}$ & $\begin{array}{l}\text { 61.0歳 }(\mathrm{SD}=10.3) \\
11.6 \text { 年 }(\mathrm{SD}=7.1)\end{array}$ \\
\hline $\begin{array}{l}\text { 障害者と同居の割合 } \\
\text { 家族会所属者の割合 } \\
\text { 老齢年金生活者の割合 } \\
\text { 年収250万円以下の割合 }\end{array}$ & $\begin{array}{ll}82.4 \% & \text { (28名) } \\
38.2 \% & \text { (13名) } \\
55.9 \% & \text { (19名) } \\
14.7 \% & \text { (5名) } \\
\end{array}$ \\
\hline $\begin{aligned} \text { 最終学歴: } & \text { 大学 } \\
& \text { 短大 } \\
& \text { 高校 } \\
& \text { 義務教育 } \\
& \text { その他 }\end{aligned}$ & $\begin{aligned} 17.6 \% & \text { (6名) } \\
8.8 \% & (3 \text { 名 }) \\
29.4 \% & (10 \text { 名 }) \\
35.4 \% & (12 \text { 名 }) \\
8.8 \% & \text { (3名) }\end{aligned}$ \\
\hline $\begin{aligned} & \text { 障害者との続柄：父親 } \\
& \text { 母親 } \\
& \text { 同胞 } \\
& \text { 配偶者 }\end{aligned}$ & $\begin{aligned} & 20.6 \%(\text { 7名 }) \\
& 58.8 \% \text { (20名) } \\
& 14.7 \%\text { (5名 }) \\
& 5.9 \%\text { ( 2名 }) \\
&\end{aligned}$ \\
\hline \multicolumn{2}{|l|}{ 障害者（34名：男21, 女13） } \\
\hline $\begin{array}{l}\text { 平均年齢 } \\
\text { 平均初発年齢 } \\
\text { 平均入院頻度 } \\
\text { 平均総入院期間 }\end{array}$ & $\begin{array}{r}38.9 \text { 歳 }(\mathrm{SD}=13.5) \\
23.2 \text { 歳 }(\mathrm{SD}=6.9) \\
1.8 \text { 回 }(\mathrm{SD}=1.7) \\
4.3 \text { 年 }(\mathrm{SD}=9.1)\end{array}$ \\
\hline $\begin{array}{l}\text { 診断名「分裂病」の割合 } \\
\text { 有職者(パートタイム)の割合 } \\
\text { 作業所通所者の割合 }\end{array}$ & $\begin{array}{rr}91.2 \% & (31 \text { 名 }) \\
5.9 \% & (2 \text { 名 }) \\
41.2 \% & (14 \text { 名 }) \\
\end{array}$ \\
\hline $\begin{aligned} \text { 最終学歴: } & \text { 大学 } \\
& \text { 短大 } \\
& \text { 高校 } \\
& \text { 義務教育 }\end{aligned}$ & $\begin{array}{ll}23.5 \% & \text { ( 8名 }) \\
11.8 \% & \text { (4名) } \\
47.1 \% & \text { (16名) } \\
17.6 \% & \text { (6名) } \\
\end{array}$ \\
\hline $\begin{array}{l}\text { 障害者の自立度 (家族判定)： } \\
\text { 家庭管理等の自立 } \\
\text { 日常生活の自立 } \\
\text { 声掛けが必要 } \\
\text { 半介助が必要 } \\
\text { ほぼ全介助が必要 }\end{array}$ & $\begin{array}{r}17.6 \% \text { (6名) } \\
32.4 \% \text { (11名) } \\
38.2 \% \text { (13名) } \\
8.8 \% \text { (3名) } \\
2.9 \% \text { (1名) }\end{array}$ \\
\hline
\end{tabular}

由に具体的に体験を物語ることができるように 進めた。また，できごとを比較する質問や例外 的なできごとに関する質問を準備し，他に，ケ ア提供に関する記録や思い出の品があれば，そ れらを題材にして話を聞いた。

デー夕収集は1999年1月から 12 月にかけて行 った．面接の回数は一人あたり 1 回から 4 回まで とばらつき，面接時間も，対象の都合により， 一人あたり 2.5 時間から 8 時間とばらついた。平 均面接時間は $3.6( \pm 1.6)$ 時間であった。インタ ビュー内容は，参加者から録音の許可を得るこ とができた場合録音したが，録音許可を得るこ とができなかった場合は，許可を得て面接中に メモをとった．参加者 34 名中 27 名 $(79.4 \%$ ) が録 
音を許可した。

\section{4 データ分析}

分析はLofland とLofland (1995)による分析的 コーディングの技法に準拠して行った。分析的 コーディングは質的な分析方法であり，初期コ ーディングと焦点を絞ったコーディングからな る.

初期コーディングでは，データのコード化と， 類似したコードのカテゴリー化を行った。そし て，複数の事例や場面に共通したコードやカテ ゴリーが繰り返し出現してきた時点で，焦点を 絞ったコーディングに移った。

焦点を絞ったコーディングでは，複数の事例 や場面を対比・関連させ，類似したパターンを 示す事例からはカテゴリーの特性や出現条件を 同定し，対照的なパターンを示す事例あるいは 相違点の明瞭な事例間の比較からはカテゴリー 間の境界を同定した。並行して, 複数のカテゴ リーのうち現象を最も包括的に説明しうる中核 的なカテゴリーを発見し, 仮説を生成する作業 を行った．生成された仮説でデー夕を再分析し， 仮説とデー夕間の適合具合を検討した，適合具 合が悪い場合は，仮説の修正及びデータの補充 を行い，修正された仮説でデー夕を再分析する 過程を繰り返した。

表 2 は初期コーディングの作業例である。例示 した事例では，医療の継続，居場所の確保，生 活費の確保等のコードが療養生活の支援として カテゴリー化された。 そして, 社会復帰の手伝 いだけである旨を伝えるなどのケアの仕方は， 一線を画すとしてカテゴリー化された，療養生 活の支援に関するコードと，一線を画すという ケアの仕方に関するコードから, 療養生活の支 援は障害者の生活を保障する機能があり，一線 を画すケアは家族自身の生活を守る機能がある のではないかと解釈した。

また，この事例では，自分にも生活がある， ケアを放棄したい，とコード化されているが， 類似したコードは他の場面や他の事例でも, 繰 り返し出現していた。ことに，障害者の生活を 守らなければならないが，自分の生活も守りた いという家族の心情を示すコードと, 障害者の
生活を守る対処及び家族自身の生活を守る対処 を示すコードは，多くの事例に共通していた。 そこで，焦点を絞ったコーディングに移り，大 多数の事例に共通して出現した「障害者の生活」 と「家族の生活」に関するデー夕に選択的に注 目し，複数の事例や場面を対比・関連させてい った。その過程で複数の対処様式が析出された。 定性研究における妥当性は, 現象の解釈が特 定の学問的立場から了解可能であることで確保 される(古賀, 1997)。デー夕分析の妥当性に関し ては，修士以上の学位を持つ精神科臨床経験 4 年以上の看護教員 5 名から批評を受け，調査参 加者からも意見を聞いた。

\section{III 結 果}

\section{1 家族の対処椂式}

分析の結果, 精神障害者をケアする家族成員 の対処として，一体型，無関与型，叱咤激励型， 共栄型，空転型，諦め型6種類の対処様式が析 出された (表 3$)$ 。そのうち, 無関与型と叱咤激 励型は，障害者への関わり方に差があるものの， 障害者と家族のニーズの優先具合は共通するこ とから，自己保存型にカテゴリー化された．同 様に，空転型と諦め型は無力型にカテゴリー化 された。その結果，一体型，自己保存型，共栄 型，無力型の 4 種類が，基本的な家族の対処様 式として析出された。 以下に，家族の基本的な 対処様式について述べる.

\section{1) 一体型}

一体型は，障害者の生活に焦点がおかれ，家 族成員自身の生活は従属的になっている対処様 式である。一体型では，家族成員と障害者の関 係は密着しており，しばしば家族成員は障害者 のケアに常時全面的に関与している．家族成員 の障害者に対する共感性は高く，障害者の状態 の変化に一喜一憂し，障害者の苦しみに同調し， 障害者の動摇と共に摇れ動いている，家族成員 の関心は現時点における障害者の苦痛緩和に集 中し，障害者の将来に漠とした不安を持ってい ても，障害者の未来に向けた働きかけはない． また，家族成員は障害者と共に，家庭内という 限られた世界に閉ざされて生活している。この 


\begin{tabular}{cl}
\hline ヨ & $-1 ゙$ \\
\hline 必要時以外は親に任せる
\end{tabular}

親に姉の入院を勧める，親にすべて任せ る，親から相談されれば姉と関わる

\section{療養生活の支援}

医療につなぐ：従姉に病院のことを相談 する，入院先を探す

療養を継続させる：療養の継続方法を自 分で調査する, 主治医やワーカーに継続療 養の方法を相談する

居場所を確保する：ワーカーや保健師を 介してグループホームを見つける，保健師 を介して作業所を見つける

生活費を確保する：福祉の手続きを助け る，姉のために遺産を放棄する

\section{一線を画す}

自分の限界を伝える：保護者にはなれな いと伝える，社会復帰の手伝いだけと伝え る，同居は無理であると伝える

援助を限定する：トラブル時には出向く が普段は電話で話を聞く

\section{自分の生活を守りたい}

自分にも生活がある：自営業が大変, 「年だ」，自分の夢を実現したい

ケアを放棄したい：もう縁を切りたい， もう限界，蒸発したい

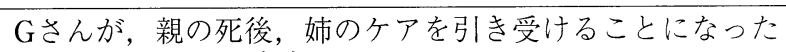
いきさつとケアの内容

Gさんの姉は, グループホームに住み，作業所に通ってい
る. 以前は暴力が頻繁で飲酒もしていたが，最近はやや落 ち着き，現在の主な問題は，他者への迷惑行為である。 $\mathrm{G}$ さんは両親の死後姉の面倒をみ始めた。両親の存命中, $G$ さんは父親に姉の入院を勧めたが，「家から精神病を出せ ない。家でみる」と断られた。それ以降，姉のことはすべ て両親に任せ，親から相談があったとき以外は，姉のこと には一切関わらなかった。

父親の死後早速，従姉に病院を調べてもらい，入院先を探 し，姉に治療を受けさせた。退院時には，継続療養の方法 を調べ，主治医やケースワーカーにも相談した。ワーカー を通じて，姉の居住区であった保健所保健婦を紹介され， そのつてで現作業所とグループホームを探し, 姉の退院に 備えた。また，遺産がすべて姉の方にいくように手続きし， 姉が生活保護と障害年金を受給できるように手伝った。

退院時，姉には，自分には自分の生活があるため姉の生活 を助けるにしても限界があること，保護者になることはで きないこと，社会復帰の手伝いをするだけであること，同 居が無理であることなどを伝えた，Gさんによると，家族 にもできることとできないことがあるので，引き受けるこ とに線を引いているとのことである，Gさんは，そうする ことで，姉のためにできることが見えてくると考えている. 現在，Gさんは，姉が他者とトラブルを起こした場合には， 直接出向いて調整にあたるが，普段は，電話で姉の話をじ っくり聞くだけにしている.

なお，Gさんは，30代の頃，姉と両親を面倒見ようと考え ていたが，40代後半の今，自営業の維持も大変で，「年で」 自分自身のエネルギーが低下しており，姉のことより，自 分の夢を追求したいと考えている。また，これまでも何度 となくトラブル処理をしてきたこともあり，これ以上トラ ブルを起こしたら，もう縁を切りたいと思っている。 また， 姉に対して「そういう病気で可哀想」という同情はあるが, 姉が両親の命を縮めたと考え，姉を許せず，姉に対して愛 情をまったく注げないと言う。今はたた「親孝行できるな と思った矢先に死んでしまった」両親に対する済まない気 持ちから，姉を援助している。「親父は石屋で職人気質だっ た。保守的なのに俺を大学にまで行かせてくれたのは，家 の中に新しい風を吹き达んでくれ，俺の考えてることに反 対してくれ，と思ってたからじゃないか」と考え，亡き親 の供養のため，姉のことを看続けていこうと考えている.

しかしその一方，もう自分としては限界たという気もして 拈り，姉の前から「蒸発」することも真剣に考えている。

覚書：(1)『療養生活の支援』の特徵は，自分でできることをしているが，親族や専門家の力も借りてい る。

(2)療養生活の支援は，姉の生活を保障する機能がある.

(3)一線を画すケアは，自分の生活を守る機能がある.

(4)自分の方が大変でもう面倒を見たくないという思いがある半面，本人の療養生活を助けるため の行動をとっている。

(5)ケアをできる自分の状況でもないし，積極的な関与は避けたいところであるが，姉の状況と親 への恩を考えるとケアをせざるを得ない，と考えている。

複数の場面や事例と共通するテーマなど :

(1)自分の生活を守りたいが，障害者の生活も守らなければならない，という心情が頻繁に語られ る.

(2)自分の生活を守る対処と，障害者の生活を守る対処が頻出する.

(3)一線を画している事例とは対照的に，距離をとれない事例も多い. 
表3 精神障害者をケアする家族成員の対処のタイプ

\begin{tabular}{|c|c|c|c|}
\hline タイプ & グループ化されたコード & $\begin{array}{l}\text { 障害者と家族の } \\
\text { ニーズの充足具合 }\end{array}$ & 出現しやすい条件 \\
\hline 一体型 & $\begin{array}{l}\text { 障害者に駄目と言えない } \\
\text { 障害者に代わって障害者のニーズす } \\
\text { べてを満たす } \\
\text { 障害者と一体化して摇れる } \\
\text { “1日24時間世話役” } \\
\text { ひとりで全てを背負う } \\
\text { 障害者と共に家庭内にひきこもる }\end{array}$ & $\begin{array}{l}\text { 障害者のニーズを優先し, } \\
\text { 家族のニーズは二の次 }\end{array}$ & $\begin{array}{l}\text { 発病の初期や再発時など障 } \\
\text { 害者の苦痛が大きいとき }\end{array}$ \\
\hline $\begin{array}{l}\text { 吨 咤 } \\
\text { 激励型 }\end{array}$ & $\begin{array}{l}\text { 自分の立場から話す } \\
\text { 障害者のニーズには無頓着 } \\
\text { 障害者を叱咤激励する } \\
\text { 自分の都合で関わる } \\
\text { ケアは主たるケア提供者にほぼ任せ } \\
\text { きり } \\
\text { 自分の社会生活は維持 }\end{array}$ & $\begin{array}{l}\text { 家族の価値に従わせようと } \\
\text { して, 障害者のニーズは二 } \\
\text { の次 }\end{array}$ & $\begin{array}{l}\text { 障害や障害者を認められな } \\
\text { いとき, または世間体が気 } \\
\text { になるとき } \\
\\
\text { 父親に多い }\end{array}$ \\
\hline $\begin{array}{l}\text { 無関与 } \\
\text { 型 }\end{array}$ & $\begin{array}{l}\text { 障害者に関与しない } \\
\text { 障害者のニーズには無関心 } \\
\text { 障害者に関与しない } \\
\text { 自分の生活に専念する } \\
\text { ケア主たるケア提供者に全面的に } \\
\text { 任せきり } \\
\text { 自分の社会生活は維持 }\end{array}$ & $\begin{array}{l}\text { 家族自身のニーズを優先し } \\
\text { て, 障害者のニーズは無視 } \\
\text { する }\end{array}$ & $\begin{array}{l}\text { 障害や障害者を認められな } \\
\text { いとき,または自分の家庭 } \\
\text { や職業を守らなければなら } \\
\text { ない事情があるとき } \\
\text { 父親や同胞に多い }\end{array}$ \\
\hline 共栄型 & $\begin{array}{l}\text { 障害者の立場から話す } \\
\text { 障害者ができることはさせる } \\
\text { 障害者の気持ちを受けとめる } \\
\text { 自分の時間を作り, 健康に留意する } \\
\text { 協力者を得る } \\
\text { 障害者と共通の社会生活がある }\end{array}$ & $\begin{array}{l}\text { 障害者と家族双方のニーズ } \\
\text { を充足する }\end{array}$ & $\begin{array}{l}\text { 障害を受容し, 障害者の未 } \\
\text { 来及び社会生活が視野にあ } \\
\text { るとき } \\
\text { 経験者や学習者に多い }\end{array}$ \\
\hline 諦め型 & $\begin{array}{l}\text { 障害者の“飼い殺し”状態 } \\
\text { 障害者の様子を垣間見ながら関わる } \\
\text { 障害者のケアも自身のケアも最小限 } \\
\text { 自分の社会生活が避難所となる }\end{array}$ & $\begin{array}{l}\text { 障害者と家族双方のニーズ } \\
\text { は充足されない }\end{array}$ & $\begin{array}{l}\text { 障害者側の拒絶が強いと } \\
\text { きまたは進展のないまま } \\
\text { ケアが長期化しているとき }\end{array}$ \\
\hline 空転型 & $\begin{array}{l}\text { 障害者に振り回される } \\
\text { 障害者の様子を窺いながら関わる } \\
\text { 障害者のケアも自身のケアも最小限 } \\
\text { 自分の社会生活が避難所となる } \\
\end{array}$ & $\begin{array}{l}\text { 障害者と家族双方のニーズ } \\
\text { は充足されない }\end{array}$ & $\begin{array}{l}\text { 障害者側に暴力, または広 } \\
\text { 範かつ深刻な問題行動があ } \\
\text { るとき }\end{array}$ \\
\hline
\end{tabular}

対処様式は，障害者のニーズを優先的に満たす 機能を持ち，障害者の発病後間もない時期に生 じやすい，以下は，娘の再発に心を痛めている 50 代前半の母親の話である.

○○もいつまでも若くないしね， ああこのまま 駄目になっちゃうのかなあって, もう毎日毎晚, 兴の事は頭から離れないから... (間) ... ずー っとこれで，28，29，30と年とっていくんだ けど，一体これからどうなるんだろうかなあ, 本人が一番かわい关うだなあって思うんですけ どね... (間)....主人の方から，お母さんは关 んなに思い詰めちやつたんじや，絶対に体壊す
から，一緒になって兴んなに悩んでもしょうが ないからねって，言ってくれるんですけどね. でもねえ，かわい关うだなあって思っちゃうん ですよね．気持ちが入り過ぎて，ともにねえ， ともに神経の方がおかしくなっちゃう.

たたし，一体型の対処様式は，家族成員自身 のニーズを軽視する危険性と障害者のニーズを 過多に満たす危険性を孕んでいる.

本人が不安だって言えば，夜中中ついてて背中 をさすってあげたり，話聞いてやったりするわ けですよ，兴んなことやってたらこっちの身も 
もたないけど，親としては心配でしょ．..(中 略)…面倒見過ぎて，子どもが救われる場合 もあるでしょうし，かえって逆に余計なお節介 をやく場合もある、私がいなければ，子どもは 自分の判断で明日まで我慢しようとか, 自分で 乗り越えようとかできるかもしれないけど，私 たちがいるために, 私たちがいろんなケアをす るから，依存してくるってこともあるでしょ．

\section{2 ) 自己保存型}

自己保存型は，家族成員自身の生活を優先し， 障害者の生活は二義的になっている対処様式で ある，自己保存型では，家族成員と障害者の関 係は疎遠で，家族成員は自分の都合で断片的に 障害者と関わっているか，全く関与しない. 家 族成員の障害者への共感性は低く, 時間は過去 に逆行し，家族成員は障害者が「元に戻る」こ とを期待して障害者を叱咤激励したり，時には 障害者を切り捨てる。また，家族成員の社会と の接点は，障害者を抜きにした形で保たれてい る.この対処様式をとることにより，家族成員 自身の身は守られ, 障害者のニーズ充足は家族 成員のニーズ充足より後にくるか, 軽視ないし 無視される。この対処様式は, 家族成員自身が 障害や障害者と真正面から取り組みたくないと き，ないし障害や障害者を拒絶しているとき， あるいは家族が自分たちの課題で手一杯のとき に生じやすい，以下は，障害を受け入れられな かった時期を振り返り, 自分たちの視点から一 方的に関わっていたという母親の話である.

病気が落ち着けばね, 特に手がかかるってほど でもないんですよ.でもね, うちも商売してま したしね, 親としては, やっぱり子どもが何も しないで家でゴロゴロ寝てると目障りになって くるんですね. 足が悪いとか, 手が悪ければ, もうあの子は障害者だからしょうがないと諦め もあるけど，五体満足の息子が家で何もしない でゴロゴロしてんのは，やっぱり親にとっては 目障りなんですね. 親にしたって, まだ炎の頃 は精神病を受け入れられない. 急け者にしかや っぱり見えなかったですもんねえ. 今なら病気 を受け入れる気持ちになってるけど, 病気を発
病した当初は子どもを受け入れられなかったで すもの. 怠け者だってことでね, 「急け者, 兴 んなことでどうする!」っていうふうな考えが やっぱり親の中にありますからね，父親なんか は特にね、「いやお前は病気なんかじゃない， しっかししろ!」って吅咤してね.

\section{3 ) 共栄型}

共栄型は，障害者の未来を視野に含めて，障 害者の生活も家族成員自身の生活も保障しょう とする対処様式である。共栄型では，家族成員 は障害者との間にほどよい距離を持ち，障害者 の必要に応じて援助を提供している，家族成員 の共感性は適度に高く保たれた状態にある。ま た，家族成員は障害者の未来を意識しながら， 障害者の現在と未来に役立ちそうな援助方法を 試みている。家族成員自身の社会との接点は障 害者を含める形で保たれており，家族成員も障 害者も, 身内や専門職からの援助や職場の理解 を得て，地域資源を活用している。この対処様 式は，障害者及び家族成員双方のニーズを充足 する機能を持ち，経験を積みケアにある程度の 自信をつけた家族にみられる，以下は，息子と の関わりにおいて「この子の役に立っているか」 という視点から自分のケアを点検している母親 の例である。

彼はですね, 月曜日から金曜日までは作業所だ けで，土曜日は作業所のオープンスペースに必 ず来る、日曜日の午前中はうちで基会所 [息子 が喫茶店のようなものをやりたいとか言ってい たことから，5年前に始めたもの]. 午後からは レコード聞いたりして遊んでますねえ，あと 時々家族で走りに行くとか, 映画を見に行くと か... (中略).... お金を自分で管理するように なったし，年金をいただくようになったから， 食費として3万円下さい(笑)とか，息子からも らってます。私は午前中ちょつとだけ家族会の 事務所に顔出して, 外の団体との交渉とか, 事 務所に誰か来られないときの当番とかですね. 午後はうちのすぐ产ばで碁会所, 夕方までやっ てるんです、あと, 私自分もしっかり生きなけ ればいけないし, 自分が楽しければこの子にも 
いいのかなあと思ったから, 兴の頃から山に行 ったり，㫕んな時間を持つようになりました ね... (中略) ... 周囲の人にはあらためて分裂 病ですとは言わないんですけど, 大変なんだろ うねえとか，本人悩んでんだろうねえとか，お かしくなったねえ(笑)とか，なぜか開放的にし てます．他の家族が私のことを「よく关ういう ふうにしてオープンにできるね」って. だって あの人, 地元で, あ㚇こで生きていかなきやい けないし，一歩出るとね， あの人パフォーマン スして歩く人だから(笑), 知られちゃうしね, 弚うもいかないでしょ。

\section{4 ) 無力型}

無力型は, 障害者の生活も家族成員自身の生 活も保障されない対処様式である. 無力型では, 障害者との関係は遮断され，家族成員の共感性 も失われている。家族成員の社会との接点は, 一時的な避難所という形で維持されているが, 通常, 職場等の狭い社会に限られている。この 対処様式は，障害者が家族やケアを拒絶してい る時, 障害者の暴力行為や問題行動が深刻・広 範な時に生じやすい，時には，家族の抱える課 題が大きい場合にも生じる.この対処様式では, 障害者と家族成員双方のニーズは充足されず， 両者が共倒れになる危険性が高い，以下は，障 害者本人から拒絶され，自分では対処の仕様が なく，一時期は仕事も手につかず，食欲も落ち, 不眠にもなったという配偶者の例である.

自分ではどうしたらいいのかとは思うんだけど, 結局, まるっきり拒絶されているような感じだ から，全然向こうは受け入れようとしないし...

(間)....成す術がないって感じでしたよね. 仕 事から帰って来ても，出掛けるときも，ずっと 音楽を聞きっぱなしで，兰れで亡霊が見えると か，何かの声が聞こえるとかって，ずっと起き てる.ん一, どうしたらいいのか悩んでいたん だけど, どうして欲しいのか, どういうことが いやなのか，全然わからない状態だから，どう にもできないですよね. 何事にも拒絶されちゃ ってるわけだから. どんなことしてあげればい いのかは全然わからないし，たとえば，どっか
足が痛いとかいう状態だったら足さすってあげ るとかなんかできるだろうけど ... (間) ... 実 際に自分自身何もできないのが歯痒くて辛いん だけど，かと言って，こうしようと思っても， 実際には無視されてる状態だから，どうしよう もないですよねえ. だから結局, 自分としても, 自分のよ゙こが悪いんだろうってことばっかりで ね，仕事してても，いつも关んなこと考え込ん で. 他のこと [自分の生活や子どもたちの生活 に気を配ること］まで全然頭が回らなかったで すよねえ。

\section{2 対処様式間の移動}

家族成員の対処様式はひとつに固定されてい るわけではなく, 対処様式間の移動が生じるこ ともある。例えば，一体型の家族成員が障害者 への長期間の全面的関与によって消耗した結果， 無力型や自己保存型に移行する場合がある。あ る母親は一体型の対処をとっていたが，障害者 の広範な問題行動に振り回され続けた結果, 精 神的にも身体的にも疲弊し, 障害者への共感も 低下し，「自殺でもしてくれればいい」と願った ことがあることに言及した。この母親は一時期 自己保存型の対処様式に移行したが，現在では 周囲からのサポートとケア提供上の知識を獲得 し，障害者当人の状態もある程度落ち着いてい ることから，共栄型に移行している.

同様に，自分の生活を優先していた自己保存 型の家族成員が，障害を受け入れるようになっ た結果，共栄型に移行することもある．以下は， 専門家による働きかけにより，自己保存型から 共栄型に移行した70代の同胞の語りである。こ の同胞は，現在，兄の地域生活を支援するかた わら若年の障害者たちの自立に手を貸している.

できれば病院でこのままお世話していただきた いというのが当時の私の意見でした．これは極 めて現実的な考えで，兄が入院する前とは家の 状況が変化してるし，生家に連れて帰るわけに はいかないですよね，病院で預かってもらえれ ば，環境にも恵まれてるし，治療もしてもらえ る. 患者にとっても家族にとっても総合的にい 
いと思ったんですよ.しかし今考えると一つの 逃げだったかもしれないなあと思います，真に 患者の立場に立っていなかったなあと反省して います。本人には本人の生活があるんですよ. 入院させておきたいというのは, こちら本意な 考え方であって ... (中略) ....でも患者が自立 して生活していけるという体制が整っていない と，こちらとしてもいいとは言えない，兴の点 は，病院のスタッフが訓練をしてくれました。 「お兄さんは食事は作れる, タバコは吸うけれ ども八の始末もできる, 洗濯もできる」などな ど，ちゃんとできるんだということを丁寧に説 明してくれました，关れで「住まいも病院の近 くで，こちらの作業に通ってくれば生活のリズ ムもできる，家にこもりっきりってことにはな らない，食事は職員食堂で食べればいい，病院 と関係が切れるわけではない」などと丁重な説 明を聞くと，決断を迫られるわけですよ，彼に は彼の人生があるわけですからね，私は守旧派 的な考え方だったのですが，意識改革を迫られ るのですよ.

\section{$\mathrm{V}$ 考 察}

\section{1 家族の対処樣式}

析出された基本的な対処様式を比較すると， 一体型と共栄型の対処には, 障害者に代わって ニーズを満たす，障害者と一体化して摇れる， 障害者の立場から話す，障害者の気持ちを受け とめる等の特徵があり, 家族が障害者のニーズ に共感的に応える働きが内包されている。また， 自己保存型と共栄型の対処には, 自分の社会生 活を維持する，自分のことに専念する，自分の 時間を作る，自分の健康を守る等の特徵があり， 家族が自分自身のニーズに配慮する働きが内包 されている。一方，無力型の対処は障害者への 共感性も家族自身への配慮も欠いている。つま り, 各対処様式は, 家族が障害者のニーズに共 感的に応じる『家族の応答性』と, 家族が家族 自身のニーズに配慮する『家族の自己配慮』と いう二つの軸の組み合わせによって説明でき， その組み合わせが家族の対処様式を決定してい
ると考えられる，図1は，『家族の応答性』を横 軸に『家族の自己配慮』を縦軸にプロットして 各対処様式を示したものである。なお，叱咤激 励型と無関与型は自己保存型の，諦め型と空転 型は無力型のバリエーションと考えられる.

先行研究においては, 精神障害者の家族の対 処として, 受容, 安心の保障, 強要, 放棄, 諦 めなどが報告されている(Birchwood と Cochrane, 1990 ; Magliano ら, 1998). 先行研究 に扔ける強要や放棄は本研究の自己保存型の対 処と, 諦めは本研究の無力型の対処と, 内容的 にほぼ相応している。また，心身障害者の家族 の苦悩について言及した南雲(1998)は，障害者 の家族の苦悩が家族の「同体」としての側面か ら生じ，家族が障害者の苦悩を我が事のように 共有してしまうことを指摘している。本研究に おける一体型の対処では，家族は障害者の苦悩 に同調し，障害者とともに摇れ動いており，南 雲の言う家族の同体としての側面に通ずると考 えられる。加えて，家族が精神障害者のニーズ に共感的に応じかつ自分自身のニーズに配慮す る対処をとっていることが報告されているが (岩㟝, 1998 ; 宮㟝ら, 2001 ; Spaniolら, 1987), これに相当する対処が本研究における共栄型の 対処だと考えられる.

家族の対処を規定する要因に関する先行研究 は見当たらないが，上述のと扔り，複数の先行 研究において, 家族が精神障害者のニーズに共 感的に応じると同時に自分自身のニーズに配慮 していることが明らかにされていることから，

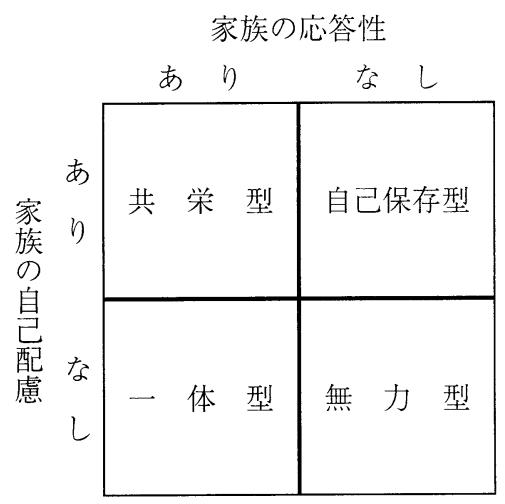

図1精神障害者をケアする家族成員の対処様式の 規定要因及び基本的対処様式 
家族の対処を，家族の応答性と自己配慮という 二つの次元から捉えることは概ね妥当であるこ とを示唆していると考えられる。しかしながら， 先行研究において, 家族の対処は障害者の状態 や問題行動にも影響を受けていることが報告さ れており(Birchwoodら, 1990 ; Maglianoら, 1998), 本研究においても, 障害者側の要因が 家族の対処を規定する一要因であることが類推 された。ただし，いずれの研究においても，障 害者は研究の対象として含まれていないため, その検証は今後の課題となる。

\section{2 対処様式間の移動}

家族は対処様式間を移動するが，対処様式間 の移動には，家族の『応答性』と『自己配慮』 間における葛藤の顕在化が影響していると考え られる。つまり，家族には障害者の生活を優先 させるか又は自分の生活を優先させるかという 葛藤が潜在しており, 家族が障害者の生活の質 と自分の生活の質を同等に保障することが困難 になったとき，『応答性』と『自己配慮』の間で 葛藤が顕在化し，家族はケアをしてやりたいと いう思いとケアを放棄したいという思いの間で 摇れると考えられる.

そして，葛藤の顕在化に影響する一要因とし て，ライフサイクルが考えられる。例えば，親 がケア提供者の場合，障害者の発病は，職業 的・社会的責任を果たすことが期待される中年 期と重なることが多いが，親自身の職業生活を 優先させると, 障害者の生活は軽視され, 逆に, 障害者の生活を優先させると，親自身の職業的 成功や昇進を不意にすることもありえるため, 葛藤が生じると考えられる，実際，五十代を迎 え息子の発病を体験したある父親は，「仕事をと るか息子をとるか」で長い間悩んだ末，「仕事よ りも大事なことがある」と考え，息子との時間 を作るようにしたと語っている，同様に，家族 自身の身体的・精神的エネルギーが低下する老 年期に抒いても，障害者の生活を優先させると 家族自身の生活が脅かされ，反対に，家族自身 の生活を優先させると障害者の生活がおろそか になる可能性があることから，葛藤が顕在化す ると考えられる，ある八十代の母親は，「戦争を
くぐり抜けて，いろいろなことがあって，もう 今はこの年になったんですから，死前ぐらい はちょっとはね, フアーってゆうようなふうに して(伸びやかに) 暮らしたいなあ」と思いなが らも，「この人といて，できるだけのことはやっ てあげて，一生終えようかなあとも思ったりも するんですけども」と，相反する思いを語って いる.

家族の葛藤が顕在化する時期は，家族のケア 提供上の負担の増大と必ずしも一致しているわ けではないため, 家族負担に関する研究との比 較には慎重を要するが，家族の年齢と負担の関 係を調べた横断研究がある.Cookら (1994)の研 究では, 負担全般と家族の年齢の間には直線的 な相関も曲線的な関係も認められなかったが, 障害者への責任性に関する負担は高齢の親で高 く, 問題行動に関する負担は若年の親で高かっ た. Cookらの研究は, 負担の一部の側面が家族 のライフサイクルと関連していることを示唆し ており, 今回の研究結果と全面的に矛盾するも のではないと考える. しかし, 家族の暮藤に関 する時間軸上の変化を検証するには, 家族と障 害者双方の発達に関する縦断的な調査が必要に なる。

\section{3 看護上の示唆}

家族の『応答性』と『自己配慮』は, 精神障 害者の家族への看護上有用な概念となると考え る。まず，看護職者が家族の応答性と自己配慮 の二点に注目することで, 家族が必要としてい る看護を短時間で的確に判断し, 提供すること が可能になると考える，例えば，家族の言動か ら, 家族の応答性または自己配慮の状態を査定 するのは此較的容易であろう。そして家族の応 答性が低い場合は家族が障害者への共感性を高 められるよう援助し, 反対に自己配慮が低い場 合は家族が自身の生活の質を維持できるよう援 助するなど，家族の本質的なニーズに合致した 看護に発展させていくことができると考える.

次に，家族の『応答性』と『自己配慮』は， 家族にとっては，障害者の生活の質を保障する と同時に，家族自身の生活の質も維持すること が重要であることを示唆している。また，家族 
の応答性と自己配慮の間の葛藤が表面化しやす くなる時期が示唆されたことから，家族の暮藤 を予測しながら，家族と障害者双方の生活の質 を保障する継続的な働きかけが可能になると考 える。

最後に, 家族の対処様式が応答性と自己配慮 の組み合わせにより変化することは，弾力的な 家族の対処力をうかがわせる。家族の弾力性を 生かすことで，家族と協同して障害者の生活の 質を保障していくことが可能になろう.

\section{V 結 語}

精神病障害者をケアする家族の対処に焦点を 当てて，その特徵を明らかにした。分析的コー ディングの技法を用いてデー夕を分析した結果, ケア提供上の対処様式として, 共栄型, 一体型, 自己保存型, 無力型が析出された. 対処様式の 規定要因として，家族の応答性(障害者のニーズ に共感的に応えること) と家族の自己配慮 (家族 自身のニーズに配慮すること)が考えられた。ま た，対処様式は固定されたものではなく，家族 の応答性と自己配慮との間での葛藤が顕在化す ることに伴って変化すると考えられた，家族に 対する看護に際して，家族の応答性と自己配慮 に注目する有用性が示唆された。

なお，本研究の対象の大多数は親であり，結 果を普遍化するには限界がある。今後は対象を 拡大し, 対処様式の妥当性の検証が課題となる.

\section{謝 辞}

本研究は, 調査に参加してくださった御家族 と御家族の調査参加を承知してくださった障害 者御本人の御厚意なしには成り得なかったもの である。どの御家族も障害を抱えた子どもや同 胞や配偶者の悲しみをしっかりと受け止めなが ら，障害者の心の奥深くにしまわれた宝を取り 出して分かち合ってくださった，御家族のおひ とりおひとりに，そして障害者のおひとりおひ とりに，心から扮礼を申し上げたい。 また調査 を御承知くたさった各組織の関係者の皆様のお 力添えにも，格別にお礼申し上げたい。

なお, 本研究は平成 11 年度文部省科学研究費
補助金［基盤研究 (C)（2）課題番号 11672363］ の助成を受けて行われた研究の一部である. 本 研究はまた千葉大学に提出した博士論文の一部 である。

\section{文献}

浅井邦彦 (1998)：精神科医療・福祉と法改正. 精神神経学雑誌, 100 (12), 1039-1055.

Birchwood, M. \& Cochrane, R. (1990): Families coping with schizophrenia: Coping styles, their origins and correlates. Psychological Medicine, 20, 857-865.

Cook, J.A., Lefley, H.P., Pickett, S.A., \& Cohler, B.J. (1994): Age and family burden among parents of offspring with severe mental illness. American Journal of Orthopsychiatry, 64, 435-447.

Francell, C.G., Conn, V.S., \& Gray, D.D. (1988): Families' perceptions of burden of care for chronic mentally ill relatives. Hospital and Community Psychiatry, 39, 1296-1300.

Hatfield, A.B., Coursey, R.O., \& Slaughter, J. (1994): Family responses to behavior manifestations of mental illness. Innovations and Research, 3 (4), 41-49.

石原邦雄 (1981) : 精神病の長期化と家族の対応.

精神衛生研究, 28, 93-107.

岩㟝弥生 (1998)：精神病患者の家族の情動的負 担と対処方法. 千葉大学看護学部紀要, 20 , 29-40.

Iwasaki, Y. (1995): Coping of family members caring for the relatives with schizophrenia: A qualitative study, pp. 1-117. Unpublished Masters Thesis. College of St. Scholastica. 古賀正義(1997)：質的調査法とは何か. 北澤毅, 古賀正義編，〈社会〉を読み解〈技法 (pp. 14-22). 福村書店.

黒田研二, 山下俊幸, 平野瓦他 (1997) : 外来受 診中の精神分裂病患者の生活を支える社会 的サービスの必要量の全国推計：日本精神 神経学会・社会復帰問題委員会の全国調査 から. 精神神経学雑誌, 99 (2), 79-90.

Lofland, J. \& Lofland, L.H. (1995): Analyzing 
social settings: A guide to qualitative observation and analysis (3rd ed.). Belmont, CA: Wadsworth.

Magliano, L., Fadden, G., Economou, M., Xavier, M., et al. (1998): Social and clinical factors influencing the choice of coping strategies in relatives of patients with schizophrenia: Results of the BIOMED I study. Social Psychiatry and Psychiatric Epidemiology, 33 (9), 413-419.

宮㠃澄子, 岩㟝弥生, 石川か抢り他 (2001): 精 神分裂病患者を家族にもつ男性家族員のケ アの内容及びケア提供に伴う情緒的体験と 対処. 千葉大学看護学部紀要, 23, 7-14. 南雲直二(1998)：障害受容 [意味論からの問い]. 荘道社.
Noh, S. \& Turner, R.J. (1987): Living with psychiatric patients: Implications for the mental health of family members. Social Science and Medicine, 25, 263-272.

岡上和雄, 大島嚴, 荒井元傳編 (1988)：日本の 精神障害者.ミネルヴァ書房.

Spaniol, L., Jung, H., Zipple, A.M., et al. (1987): Families as a resource in the rehabilitation of the severely psychiatrically disabled. In A.B. Hatfield \& H.P. Lefley (Eds.), Families of the mentally ill: Coping and adaptation (pp. 167-190). New York: Guilford.

丹下祐子, 木村洋子, 岸田貞子, 白石美恵子, 福田知子 (1998)：精神障害を持つ家族の資 源的条件と日常生活上の困難。精神科看護, 66, 65-71. 